\title{
Adana Şehir Merkezindeki Topraklarda Ağır Metal Kirliliğinin Araştırılması
}

\author{
Mustafa AKYILDIZ ${ }^{* 1}$, Burcu KARATAŞ ${ }^{1}$ \\ ${ }^{1}$ Çukurova Üniversitesi, Mühendislik Fakültesi, Jeoloji Mühendisliği Bölümü, Adana
}

Geliş tarihi: 24.04.2018 Kabul tarihi: 29.06 .2018

$\ddot{\mathbf{O z}}$

İnceleme alanı Adana şehir merkezi ve çevresini kapsamaktadır. Bölgeden 52 adet toprak örneklemesi yapılmıştır. Alınan örnekler üzerinde Atomik Absorbsiyon Spektrometre cihazı ile $\mathrm{Fe}, \mathrm{Al}, \mathrm{Mn}, \mathrm{Cu}, \mathrm{Zn}$, $\mathrm{Hg}, \mathrm{Ni}, \mathrm{Cr}, \mathrm{Pb}, \mathrm{As}, \mathrm{Co}, \mathrm{Cd}$, elementlerine ait analizler yapılmıştır. Analiz sonuçları Çevre ve Şehircilik Bakanlığı Toprak Kirliliği yönetmenliğinde belirtilen standartları ile karşılaştırılmıştır. $\mathrm{Fe}, \mathrm{Mn}$ ve $\mathrm{Pb}$ elementleri standartların altında bulunurken, $\mathrm{Cu}, \mathrm{Hg}, \mathrm{Co}, \mathrm{C}$ d, elementlerinde birkaç örnek standartların üzerinde saptanmıştır. $\mathrm{Ni}, \mathrm{As}, \mathrm{Cr}$ ve $\mathrm{Al}$ elementlerine ait analiz sonuçlarında ise örnekler yaygın olarak standartların üzerinde yer almıştır. Kirliliğe sebep olan parametrelerin genellikle çevresel faktörlere bağlı olarak oluştuğu, $\mathrm{Cr}$ ve Ni element artı̧̧ında ise kısmen bölgedeki jeolojik yapının da katkısı olduğu düşülmektedir. Ayrıca toprak ve sediman numunelerinde zenginleşme faktörü, kirlilik faktörü (Cf), kirlilik derecesi (Cd) ve Jeo-birikim indeks (lgeo) değerleri de hesaplanmıştır.

Anahtar Kelimeler: Adana, Ağır metal, Toprak kirliliği

\section{Investigation of Heavy Metal Pollution in the Soil at Adana City Center}

\begin{abstract}
The review area covers Adana city center and its surroundings. 52 soil samples were taken from the region. Analyzes of $\mathrm{Fe}, \mathrm{Al}, \mathrm{Mn}, \mathrm{Cu}, \mathrm{Zn}, \mathrm{Hg}, \mathrm{Ni}, \mathrm{Cr}, \mathrm{Pb}, \mathrm{As}, \mathrm{Co}, \mathrm{Cd}$ elements were made by using Atomic Absorption Spectrometry device. The analysis results were compared with the standards laid down in the Ministry of Environment and Urban Planning's Soil Pollution directive. Fe, $\mathrm{Mn}$ and $\mathrm{Pb}$ elements were found to be below the standards, while $\mathrm{Cu}, \mathrm{Hg}, \mathrm{Co}, \mathrm{Cd}$ elements were detected above the standards in some of the samples. In the analysis results related with $\mathrm{Ni}, \mathrm{As}, \mathrm{Cr}$ and $\mathrm{Al}$ elements, samples were found to be widely above the standards. It is considered that the parameters causing pollution are generally related to environmental factors and in the $\mathrm{Cr}$ and $\mathrm{Ni}$ element increase, the reason is considered to be partly the contribution of the geological structure in the region. In addition, enrichment factor, pollution factor, pollution degree and geo-accumulation index values are calculated in soil and sediment samples.
\end{abstract}

Keywords: Adana, Heavy metal, Soil pollution

*Sorumlu yazar (Corresponding author): Mustafa AKYILDIZ, akyildizm@cu.edu.tr 


\section{GíRiş}

Yüzyılın başından itibaren sanayileşmenin hızlanması ve modern tarıma geçilmesi ile birlikte hızla artan dünya nüfusunun oluşturduğu etkiyle doğal kaynaklar büyük ölçüde tahrip edilerek kirletilmiş ve bunların sonucunda toprak kirliliği de bir çevre sorunu olmaya başlamıştır. Toprak kirlenmesi yaşayan tüm canlı organizmaları etkilemekte ve besin zincirinin son halkası olan insanları da ciddi anlamda tehdit etmektedir [1].

İz elementler toprak ana materyalinde oluşurken insan aktiviteleri sunucu topraklara katılım ile birlikte miktarları devamlı olarak artmaktadır. Bu katılımlar kimyasal gübreler, endüstriyel atıklar, maden kalıntıları ve otomobil emisyon gazları ile olabilmektedir. Başlıca toksik iz elementler; Arsenik (As), Krom (Cr), Kadmiyum (Cd), Bakır $(\mathrm{Cu})$, Kurşun $(\mathrm{Pb})$, Mangan (Mn), Civa $(\mathrm{Hg})$, Molibden (Mo), Nikel (Ni), Selenyum (Se) ve Çinko (Zn)'dur. Toprak kirliliği farklı araştırmacılar tarafından uzun yıllardır çalışılmaktadır. Bunlarda bazılar1; Tasatar [2], Toprak kirlenmesiyle ilgili sorunlar daha çok nüfus artısına bağlı üretim ve tüketim taleplerindeki artışa paralel olarak süratle gelişme gösteren endüstri ve doğa ilişkilerindeki dengesizliklerden ötürü görülen sorunlar olduğunu ileri sürmüştür. Topraklara madencilik, maden ergitme, zenginleştirme, ticari gübreler, tarımsal savaşta kullanılan toksik kimyasal maddeler ve diğer antropojenik etkilerle doğrudan ve dolaylı pek çok değişik nitelikte maddelerin sürekli olarak katılmakta olduğunu belirtmiştir. Karpuzcu [3], Toprak kirliliğinin insan faaliyetleri sonucunda doğal yapısının bozulduğunu, fiziksel, kimyasal ve biyolojik özelliklerinin değişmesi ve toprak verimliliği bozan ya da varlığını tehlikeye düşüren her türlü doğal ve teknik etkinin toprak kirleticisi olarak adlandırıldığını öne sürmüştür. Örnektekin [4], Ağır metallerin toprak yüzeyinde biriktiği toprak derinliklerine inildikçe azaldığı gözlenmiştir. Buradan hareketle toprak alt tabakalarında önemli bir kirliliğin olmadığı sonucuna varmıştır. Yükselen [5], Toprak reaksiyonu mineral elementlerinin çözünürlüğüne ve onların bitkilerce alınımına etki ettiğini belirtmiştir. Çok asitli veya çok alkali toprak koşulları bir elementin bitkilere toksik olabileceği düzeyde çözünürlüğüne neden olabileceğini veya elementin çözünürlüğünü sınırlayarak bitki gelişmesini ve sağlığını kısıtlayabileceğini öne sürmüştür. Vivenstova ve arkadaşları [6], Toprakların fiziksel, kimyasal ve biyolojik özellikleri gerek ana materyalden ve gerekse dış etkenlerden oluşan besin maddesi veya diğer elementlerin ortamda bulunuş ve alınabilirliğine etki yapacağını öne sürmüştür. Örneğin fazlaca organik madde içeren topraklarda ağır metal ve iz elementler kuvvetle absorbe edildiğinden organik toprakların çoğu besin sağlaması açısından zayıf ortamlar olarak değerlendirildiğini belirtmiş ve örnek olarak bakir eksikliğinin ortaya çıkabileceğini belirtmiştir.

Adana ve çevresinde yapılan bazı önceki çalışmalar ise; Yaman [7], Adana'da karayolu kenar topraklarında $\mathrm{Pb}$ kirlenmesinin sebeplerinin araştırmış ve yol kenarlarındaki Pb oranlarının 424 $\mathrm{mg} / \mathrm{kg}$ 'a kadar çıktığını tespit etmiştir. Bu değerin normal değerlerden 20 kat daha fazla olduğunu belirtmiş ve yoldan uzaklaştıkça $\mathrm{Pb}$ değerinde azalma gözlemiş ancak $40 \mathrm{~m}$ 'den sonra bile kirliliğin olduğunu bildirmiştir. Topak [8], Berdan Nehri (Tarsus) su örneklerinde anyon-katyon ve ağır metalleri incelemiş ve bu suların çeşitli kullanım alanlarına göre sınıflamasını yapmıştır. Araştırmacı, çalışmanın sonucunda Berdan Nehri'nin $\mathrm{Pb}, \mathrm{Cr}$ ve $\mathrm{SO}_{4}$ içeriği bakımından içilebilir su niteliği taşımadığını belirtmiştir. Aysan [9], Adana-Tarsus güneyinde yaptığı doktora tezi çalışmasında, bölgenin toprak ve sularındaki ağır metal kirliliğini tespit etmeyi amaçlamıştır. Sulardaki jeokimyasal özellikleri araştırmak amacıyla, toprak ve kil örneklerinde de ağır metal analizi gerçekleştirmiş, $\mathrm{Ni}, \mathrm{Pb}, \mathrm{Cr}$ ve $\mathrm{Cd}$ elementlerini, toprak ve kil örneklerinde de görülmediğini belirtmiştir. Kurt ve arkadaşları [10], Deliçay ile Berdan Çayı arasında kalan bölgede yaptıkları çalışmada Kuvaterner sedimanlarının mineralojik ve jeokimyasal özelliklerini araştırmış ve farklı lokasyonlardan ve değişen derinliklerden 120 adet örnek toplamışlardır. Elde ettikleri tüm verileri CBS veritabanına aktarıp dağılım haritaları oluşturmuşlardır [11]. Seyhan Baraj Gölü'nün suyunda ve sedimentindeki bazı ağır metallerin $(\mathrm{Cd}, \mathrm{Cr}, \mathrm{Cu}, \mathrm{Fe}, \mathrm{Mn}, \mathrm{Mo}, \mathrm{Ni}, \mathrm{Se}, \mathrm{Pb}$ ve $\mathrm{Zn}$ ) 
konsantrasyonlarının mevsimsel değişiminin tespit etmişlerdir [11]. Bu araştırma ile bölgedeki topakların ağır metal içeriklerinin saptanması ve gelecek çalışmalara temel oluşturması amaçlanmıștır. Çalıșma alanı yaklaşık 2,300,000 kişinin yaşadığı, yoğun sanayi ve tarımsal faaliyetlerin olduğu Adana şehir merkezi ve çevresini kapsamaktadır (Şekil 1).

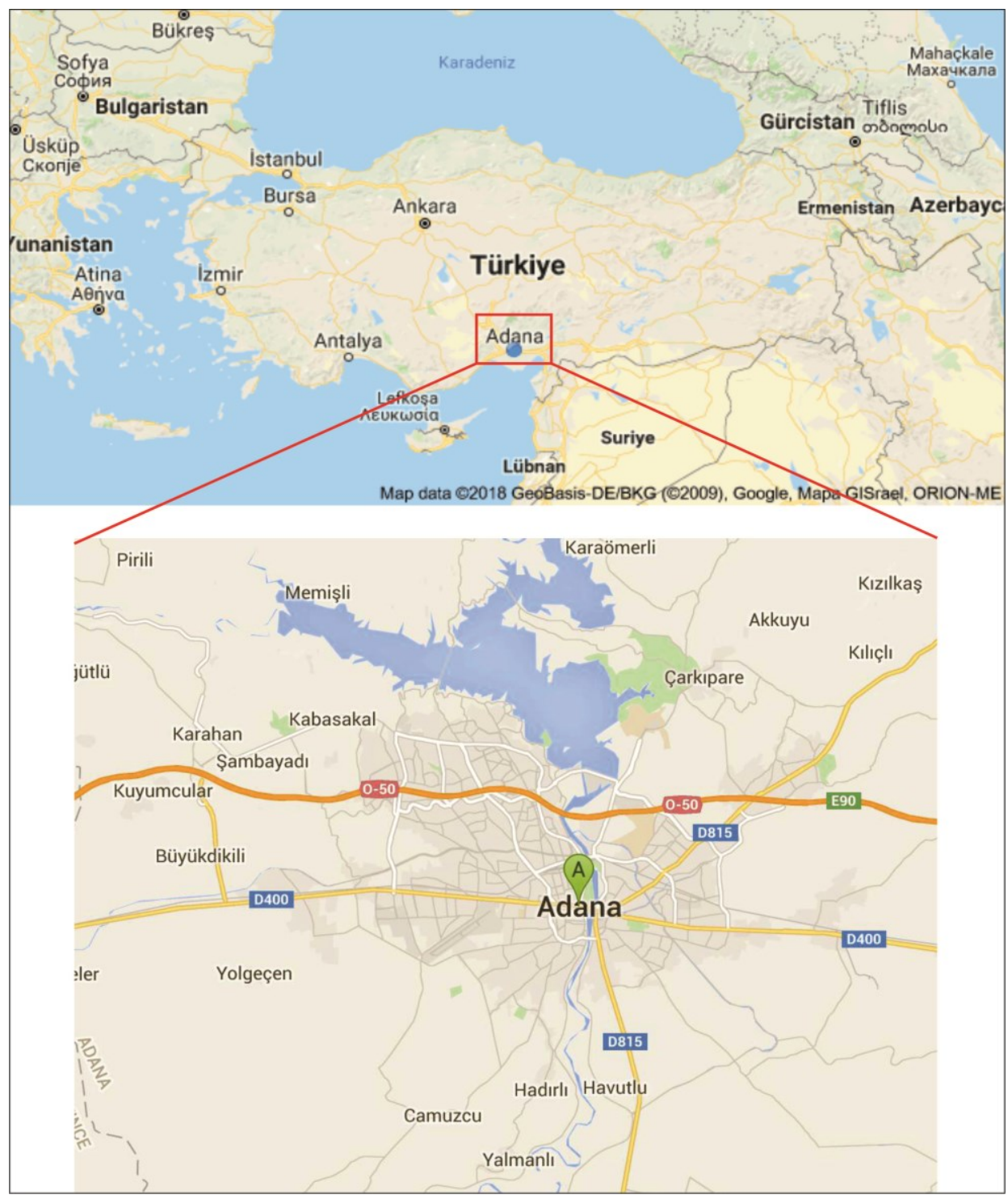

Şekil 1. Çalışma alanı yer bulduru haritası

Yerleşim merkezi, sanayii bölgeleri ve şehir merkezinden geçen Seyhan nehrindeki sedimanlar ile bunların kenarlarındaki tarımsal arazilerden toprak örneği alınmıştır (Şekil 2). Alınan örnekler Atomik Absorpsiyon cihazında yapılan ölçümler sonucunda ağır metal (Fe, $\mathrm{Al}, \mathrm{Mn}, \mathrm{Cu}, \mathrm{Zn}, \mathrm{Hg}, \mathrm{Ni}$, $\mathrm{Cr}, \mathrm{Pb}, \mathrm{As}, \mathrm{Co}, \mathrm{Cd}$ ) içerikleri tespit edilmiş ve ulusal ve uluslararası standartlarla karşılaştırılarak bölgede kirlilik olup olmadığ 


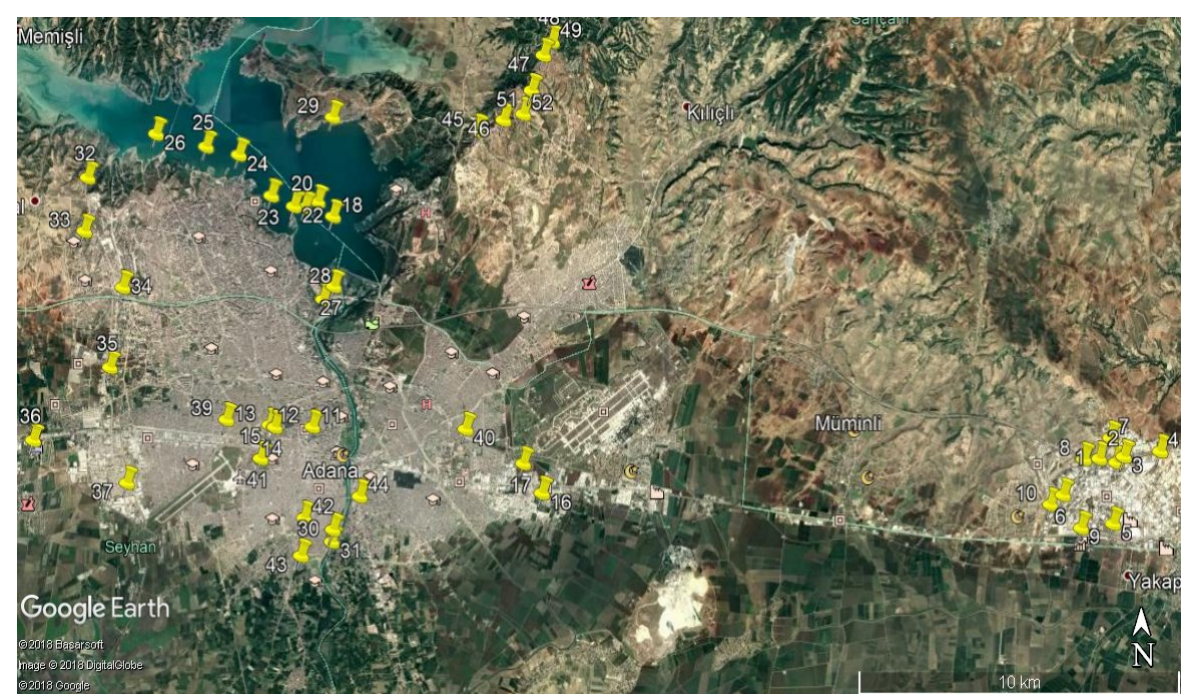

Şekil 2. Örnek alım koordinat noktaları

\section{MATERYAL VE METOT}

\subsection{Materyal}

Adana şehir merkezi, sanayi bölgelerinden ve Seyhan nehrine ait sedimanlardan 52 farklı lokasyondan örnek alımı yapılmıştır. Toprak örnekleri üstten 10-15 cm'lik kısmı kaldırılıp A zonundan (Şekil 3) alınmıştır. Örnekler yaklaşık $500 \mathrm{~g}$ ile $1 \mathrm{~kg}$ arası alınarak polietilen poşetlere konulmuştur. Örnek numaralarına göre 1-18 arası toprak örneği, 18-31 aras1 sediman örneği ve 32-52 arası yine toprak örneğidir.

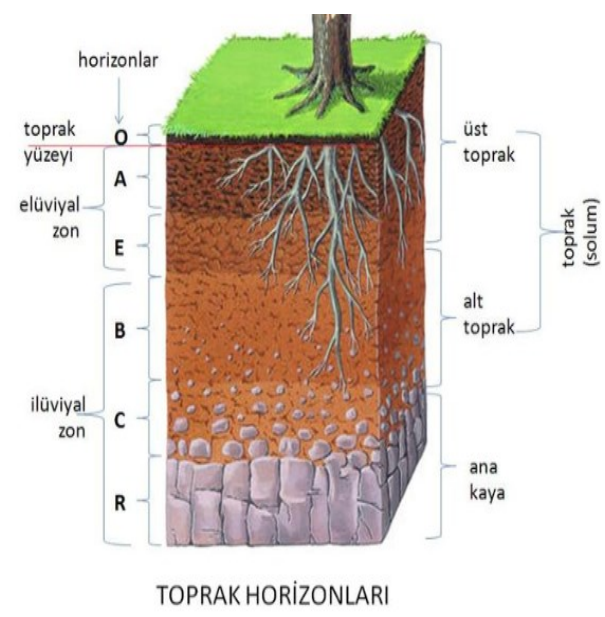

Şekil 3. Toprak zonlarını gösteren genel kesit [12]

\subsubsection{A ğır Metaller}

Ağır metaller, su ortamlarına doğal kaynaklardan ve insan faaliyetleri sonucunda karışıp, su ortamlarında ve canlılarda önemli sorunlar oluşturmaktadır. Bu kapsamda ağır metal içeren sanayi ve kent atıkları, su yardımıyla daha uzak noktalardaki büyük sulu ortamlara verilmektedir.

Metaller içerisinde yoğunluğu $5 \mathrm{~g} / \mathrm{cm}^{3}$ 'den büyük olan grup ağır metaller olarak adlandırılır. A Ăır metallere örnek olarak $\mathrm{Cu}, \mathrm{Fe}, \mathrm{Zn}, \mathrm{Pb}, \mathrm{Hg}, \mathrm{Co}$, $\mathrm{Mn}, \mathrm{Cr}$, Se, Ni, ve Cd sayılabilir. Metallerin büyük bir bölümü canlılarda birikim yapar. Birikim sonucu canlıların bünyesinde yoğunlaşan bu elementler etkili dozlara ulaştıklarında, ciddi hastalıklara hatta ölümlere sebep olabilirler.

Bazı ağır metaller canlı organizmalar için hayati oldukları halde yüksek konsantrasyonda toksiktirler. Bunlar bakır $(\mathrm{Cu}), \mathrm{krom}\left(\mathrm{Cr}^{+3}\right.$ formu), demir (Fe), mangan (Mn), molibden (Mo), çinko ( $\mathrm{Zn})$ ve nikel (Ni)'dir. Bununla birlikte kadmiyum $(\mathrm{Cd}), \operatorname{krom}\left(\mathrm{Cr}^{+6}\right.$ formu), cıva $(\mathrm{Hg})$ ve kurşun $(\mathrm{Pb})$ gibi ağır metaller canlılar için hayati olmayıp eser miktarları bile toksin etki gösterebilir.

Doğada bulanan bu elementler belli bir doza kadar canlı yaşamı için gereklidir. Ağır metallerden bir kısmı iz elementler veya eser elementler olarak da 
adlandırılabilirler. Ağır metallerin deniz suyundaki konsantrasyonları $1 \mathrm{mg} / \mathrm{kg}$ 'den düşüktür.

Ancak doğal kaynaklardan; jeolojik ve volkanik faaliyetler, erozyon, yangınlar veya insan faaliyetleri sonucunda; maden arama, işleme, evsel atıklar, tarımsal faaliyetler, endüstriyel atıklar ile derişimleri artar.

Topraklardaki ağır metallerin doğal konsantrasyonları esas olarak topraklardaki ana materyallerin tip ve kimyasına bağlıdır. Yerkabuğu, bazı sedimentler ve genellikle topraklarda bulunan bazı ağır metallerin ortalama konsantrasyonları Çizelge 1'de gösterilmiş̧ir.

Çizelge 1. Türkiye ve farklı ülkelere ait topraklardaki ağır metal konsantrasyonu sınır değerleri (Çevre ve Şehircilik Bakanlığı) ve Dünya Sağlık Örgütü ve Dünya Tarım Örgütü'nün kirlilik sinırları $[13,14]$

\begin{tabular}{|c|c|c|}
\hline Elementler & $\begin{array}{c}\text { Dünya Sağlık } \\
\text { Örgütü } \\
\text { (WHO)/Dünya } \\
\text { Tarım Örgütü } \\
(\text { FAO) }(\mu \mathrm{g} / \mathrm{g})\end{array}$ & $\begin{array}{c}\text { Türiye } \\
\text { topraklardaki ağır } \\
\text { metal } \\
\text { konsantrasyonu } \\
\text { sinır değerleri } \\
\text { (Çevre ve } \\
\text { Sehircilik } \\
\text { Bakanlığ })(\mathrm{mg} / \mathrm{kg})\end{array}$ \\
\hline $\mathrm{As}$ & 20 & - \\
\hline $\mathrm{Cd}$ & 3 & 3 \\
\hline $\mathrm{Co}$ & 50 & - \\
\hline $\mathrm{Cr}$ & 100 & 100 \\
\hline $\mathrm{Cu}$ & 100 & 140 \\
\hline $\mathrm{Fe}$ & 50000 & - \\
\hline $\mathrm{Mn}$ & 2000 & - \\
\hline $\mathrm{Ni}$ & 50 & 75 \\
\hline $\mathrm{Pb}$ & 100 & 300 \\
\hline $\mathrm{Zn}$ & 300 & 300 \\
\hline $\mathrm{Hg}$ & - & 1,50 \\
\hline
\end{tabular}

Kadmiyum, kalay ve civanın insan aktiviteleri ile toprağa birakılan en fazla metalik kirleticiler olduğu sonucuna varabiliriz. Topraklardaki kadmiyumun ortalama konsantrasyonu, tabakadaki ortalama konsantrasyonun altı katıdır. Kurşun, cıva ve kalayın topraklardaki konsantrasyonları, yerkabuğundaki ortalama konsantrasyonlarının iki katına erişir [1].

Fe, Mn, As gibi elementlere ait sınır değerler yönetmenlikte olmaması nedeni ile karşılaştırmalarda bulunmak için Dünya sağlık örgütü ve Dünya Tarım örgütünün standartlarının kullanıldığı [13] ait değerlerden yararlanılmıştır (Çizelge 1).

\subsection{Metot}

Araziden alınan numunelerin nemliliklerini gidermek için numuneler oda sicaklığında bekletilerek nemi alınıp kurutulmuştur. Kurutulan numuneler $0,1 \mathrm{~mm}$ 'lik elekten geçirilmiştir. Çözelti hazırlanması için 3 paralel 1 g'llk numunelerin üzerine $15 \mathrm{ml} \mathrm{HCl}$ ve $5 \mathrm{ml}$ litre $\mathrm{HNO}_{3}$ ilave edilmiştir. Hazırlanan bu çözelti, 1sıtıcı tablada $300{ }^{\circ} \mathrm{C}$ 'de çözündürülmüştür. Çözünen örnekler de süzme işlemi yapılarak balon jojeler içerisine alınmıştır. Toplam hacim $250 \mathrm{ml}$ oluncaya kadar ultra saf su eklenmiştir. Ağır metal analizleri Ç.Ü. Müh. Fakültesi Jeoloji Mühendisliği bölümünde yer alan Jeokimya Laboratuvarı'nda Perkin Elmer A700 Atomik Absorbsiyon spektro cihazında ile analiz edilmiştir.

\section{BULGULAR}

\subsection{Adana Yerleşim Alanı Jeolojisi}

Adana yerleşim alanı ve çevresi Adana baseninin en genç birimlerinin yer aldığı güney kesimlerinde yer alan Üst Miyosen-Pliyosen yaşlı Handere formasyonuna ait kiltaşı, kumtaşı ve çakııltaşı ardalanmalı birim ile temsil edilir. $\mathrm{Bu}$ birim üzerine Kuvaterner yaşlı taraça-kaliçi birimi gelmektedir. En üstte de güncel alüvyonlar gözlenmektedir. Handere Formasyonu Adana Baseninin güney kesiminde havza ölçeğinde oldukça yaygın bir yayılıma sahip bulunmaktadır. Formasyon Üst Miyosen-Pliyosen yaşı ile Adana grubunun en üst birimi olarak ayırtlanmıştır [15]. 
Handere Formasyonu Adana genelinde başlıca boz renkli çakıltaşı, çakıllı kumtaşı, silttaşı, kiltaşı ve yer yer alçıtaşı merceklerinden oluşmaktadır. Üzerine gelen gelip güneye doğru Adana Ovası'nın alüvyonları ile örtülü bulunan taraçaların içerisinde ve üzerinde oluşan kaliçi oluşumları kaliçileşmiş taraça olarak adlandırılmıştır. Genellikle beyazımsı kahverengi ve gri renkli olan kaliçileşmiş taraçalar kökensel olarak aynı olan ve bölgede yayılım gösteren diğer taraçaların özelliklerini taşımakla beraber çakıltaşı ağırlıklı, yer yer kumtaşı ara katkılı bir birim olarak tanımlanabilirler. Kuvaterner yaşlı alüvyon çalışma alanı içerisinde Seyhan nehir yatağı boyunca ve düz alanlarda yayılım göstermektedir.
Köşeli çakı1, kum, mil ile dere yataklarında çökelen kum, kil, mil gibi malzemeden meydana gelmiştir. Ayrıca sahanın güney ve doğusundaki geniş düzlüklerde yer alan ve kalınlığı 1-2 m olan toprak örtü de alüvyona dahil edilmiştir.

\subsection{Jeokimya}

Adana şehir merkezi ve çevresindeki 52 noktadan farklı zamanlarda örnekler alınarak Atomik Absorbsiyon Spektrometre cihazı ile Fe, Al, Mn, $\mathrm{Pb}, \mathrm{Zn}, \mathrm{Cr}, \mathrm{Zn}, \mathrm{Co}, \mathrm{Ni}, \mathrm{Cr}, \mathrm{Cu}, \mathrm{Hg}$, As, Cd element değerleri ölçülmüştür. $\mathrm{Bu}$ analizlere ait sonuçlar Çizelge 2'de verilmiştir.

Çizelge 2. Adana şehir merkezi ve çevresinden alınan 52 noktaya ait analiz sonuçları

\begin{tabular}{|c|c|c|c|c|c|c|c|c|c|c|c|c|}
\hline $\begin{array}{c}\text { Örnek } \\
\text { No }\end{array}$ & $\begin{array}{l}\mathrm{Fe} \\
\%\end{array}$ & $\begin{array}{l}\text { Al } \\
\%\end{array}$ & $\begin{array}{c}\mathrm{Mn} \\
\mathrm{mg} / \mathrm{kg}\end{array}$ & $\begin{array}{c}\mathrm{Cu} \\
\mathrm{mg} / \mathrm{kg}\end{array}$ & $\begin{array}{c}\mathrm{Zn} \\
\mathrm{mg} / \mathrm{kg}\end{array}$ & $\begin{array}{c}\mathrm{Hg} \\
\mathrm{mg} / \mathrm{kg}\end{array}$ & $\begin{array}{c}\mathrm{Ni} \\
\mathrm{mg} / \mathrm{kg}\end{array}$ & $\begin{array}{c}\mathrm{Cr} \\
\mathrm{mg} / \mathrm{kg}\end{array}$ & $\begin{array}{c}\mathrm{Pb} \\
\mathrm{mg} / \mathrm{kg}\end{array}$ & $\begin{array}{c}\text { As } \\
\mathrm{mg} / \mathrm{kg}\end{array}$ & $\begin{array}{c}\mathrm{Cd} \\
\mathrm{mg} / \mathrm{kg}\end{array}$ & $\begin{array}{c}\mathrm{Co} \\
\mathrm{mg} / \mathrm{kg}\end{array}$ \\
\hline 1 & 1,2 & 6,7 & 384,9 & 12,95 & 44,67 & 0,007 & 37,62 & $<0$ & $<0$ & 3,35 & $<0$ & 61,1 \\
\hline 2 & 2,7 & 1,0 & 858,4 & 21,26 & 46,53 & 0,000 & 63,72 & 36,6 & $<0$ & 0,21 & $<0$ & 66,9 \\
\hline 3 & 0,8 & 8,3 & 354 & 11,09 & 28,91 & 0,027 & 47,44 & $<0$ & $<0$ & 5 & $<0$ & 48,3 \\
\hline 4 & 2,7 & 9,7 & 689,4 & 19,94 & 52,62 & 0,848 & 47,71 & 11,7 & $<0$ & 3,19 & $<0$ & 75,2 \\
\hline 5 & 0,6 & 3,6 & 154,3 & 5,7 & 20,3 & 3,670 & 4,38 & $<0$ & $<0$ & 4,02 & $<0$ & 65,4 \\
\hline 6 & 2,0 & 9,1 & 558,7 & 15,01 & 51,05 & 0,142 & 43,45 & 30,1 & $<0$ & 7,16 & $<0$ & 66,0 \\
\hline 7 & 0,7 & 3,8 & 391,6 & 10,64 & 27,57 & 0,821 & 45,15 & $<0$ & $<0$ & 2,93 & $<0$ & 65,2 \\
\hline 8 & 1,1 & 3,4 & 354,7 & 20,32 & 53,79 & 0,026 & 58,84 & $<0$ & $<0$ & 4,49 & $<0$ & 61,5 \\
\hline 9 & 1,9 & 9,7 & 635 & 17,78 & 54,93 & 0,001 & 67,28 & $<0$ & $<0$ & 5,59 & $<0$ & 72,7 \\
\hline 10 & 0,7 & 3,6 & 187,1 & 5,59 & 19,19 & 0,000 & 11,51 & $<0$ & $<0$ & 3,11 & $<0$ & 74,5 \\
\hline 11 & 1,4 & 1,3 & 626,8 & 244,1 & 366,3 & 0,363 & 283,8 & 99,1 & 192,1 & 2,15 & $<0$ & 3,55 \\
\hline 12 & 1,3 & 1,3 & 544,3 & 25,03 & 58,23 & 0,012 & 349,3 & 67,1 & 109,1 & 2,7 & $<0$ & 9,64 \\
\hline 13 & 1,3 & 1,5 & 594,8 & 50,87 & 114,8 & 0,152 & 358,6 & 69,7 & 166,1 & 3,56 & $<0$ & 8,51 \\
\hline 14 & 1,6 & 0,9 & 606,1 & 16,96 & 51,98 & 0,022 & 358,5 & 62,4 & 142,1 & 2,62 & $<0$ & 12,2 \\
\hline 15 & 1,4 & 1,5 & 565,5 & 17,48 & 51,27 & 0,025 & 366,9 & 58,4 & 123,1 & 3,26 & $<0$ & 12,5 \\
\hline 16 & 1,1 & 1,2 & 563,5 & 23,91 & 73,65 & 0,011 & 357,7 & 59,5 & 131,1 & 3,35 & $<0$ & 4,16 \\
\hline 17 & 1,0 & 1,2 & 557,9 & 29,75 & 76,63 & 0,019 & 214,2 & 50,1 & 134,1 & 4,79 & $<0$ & $<0$ \\
\hline 18 & 2,4 & 2,0 & 1135 & 4,33 & 38,5 & 0,001 & $<0$ & 229,7 & 65,51 & 0,002 & $<0$ & $<0$ \\
\hline 19 & 1,1 & 1,0 & 211,4 & $<0$ & 34,2 & 0,001 & $<0$ & 172,7 & 70,3 & 0,001 & $<0$ & $<0$ \\
\hline 20 & 1,0 & 1,4 & 143,7 & $<0$ & 23,1 & 0,001 & $<0$ & 157,9 & 75,29 & 0,003 & $<0$ & $<0$ \\
\hline 21 & 1,6 & 1,0 & 193,2 & $<0$ & 33,7 & 0,001 & $<0$ & 168,9 & 68,85 & 0,001 & $<0$ & $<0$ \\
\hline 22 & 2,3 & 1,7 & 391,2 & 3,49 & 65,8 & 0,002 & $<0$ & 229,7 & 73,25 & 0,002 & $<0$ & $<0$ \\
\hline 23 & 1,1 & 1,0 & 131,2 & $<0$ & 33,3 & 0,001 & $<0$ & 141,1 & 54,66 & 0,002 & $<0$ & $<0$ \\
\hline 24 & 1,6 & 1,4 & 287,9 & $<0$ & 34,02 & 0,001 & $<0$ & 161,5 & 37,65 & 0,002 & $<0$ & $<0$ \\
\hline 25 & 2,8 & 2,3 & 727,6 & 13,83 & 59,8 & 0,001 & $<0$ & 212,9 & 63,23 & 0,01 & $<0$ & $<0$ \\
\hline 26 & 3,3 & 2,6 & 672,5 & 18,49 & 62,5 & 0,001 & $<0$ & 267,2 & 62,45 & 0,003 & $<0$ & $<0$ \\
\hline 27 & 2,5 & 1,4 & 368,8 & 28,86 & 67,51 & 0,001 & $<0$ & 88,06 & 151,6 & 0,006 & $<0$ & 18,1 \\
\hline 28 & 3,3 & 0,9 & 189,5 & 15,46 & 59,36 & 0,001 & $<0$ & 99,78 & 189,5 & 0,004 & $<0$ & 25,9 \\
\hline 29 & 0,2 & 3,4 & 43,03 & 2,69 & 8,52 & 0,000 & $<0$ & 25,21 & 36,51 & 0,0004 & $<0$ & 1,13 \\
\hline 30 & 2,3 & 1,1 & 433,4 & 544,5 & 185,6 & 0,001 & $<0$ & 128,3 & 454,1 & 0,004 & $<0$ & 12,8 \\
\hline 31 & 2,9 & 1,3 & 497,9 & 20,63 & 56,12 & 0,000 & $<0$ & 144,8 & 262,5 & 0,007 & $<0$ & 23,9 \\
\hline 32 & 1,8 & 5,1 & 333,7 & 21,19 & 55,34 & 0,032 & 141,6 & $<0$ & $<0$ & 10,57 & $<0$ & 57,2 \\
\hline 33 & 2,06 & 8,04 & 415 & 23,97 & 50,3 & 0,056 & 148,7 & $<0$ & $<0$ & 2,32 & $<0$ & 70,1 \\
\hline 34 & 1,65 & 6,39 & 345,4 & 20,59 & 43 & 0,066 & 130,7 & $<0$ & $<0$ & 7,46 & $<0$ & 60,2 \\
\hline 35 & 1,6 & 8,86 & 379 & 16,22 & 44,6 & 0,019 & 104,6 & $<0$ & $<0$ & 7 & $<0$ & 49,9 \\
\hline
\end{tabular}


Çizelge 2 (devamı)

\begin{tabular}{|c|c|c|c|c|c|c|c|c|c|c|c|c|}
\hline 36 & 2,58 & 1,26 & 609,6 & 42,44 & 65,48 & 0,016 & 141,4 & $<0$ & $<0$ & 0,18 & $<0$ & 48,4 \\
\hline 37 & 2,2 & 9,2 & 511,3 & 22,07 & 49,15 & 0,018 & 216,4 & $<0$ & $<0$ & 5,48 & $<0$ & 68,4 \\
\hline 38 & 0,93 & 6,33 & 408,8 & 14,89 & 38,12 & 0,000 & 207,8 & $<0$ & $<0$ & 3,36 & $<0$ & 61,6 \\
\hline 39 & 2,16 & 6,38 & 440,8 & 31,92 & 66,19 & 0,000 & 180 & $<0$ & $<0$ & 7,09 & $<0$ & 73,4 \\
\hline 40 & 2,5 & 1,23 & 638,9 & 21,5 & 58,37 & 0,000 & 121,1 & $<0$ & $<0$ & 9,86 & $<0$ & 63,9 \\
\hline 41 & 2,52 & 7,46 & 533,4 & 78,5 & 123,7 & 0,495 & 200,8 & $<0$ & $<0$ & 16,02 & $<0$ & 61,8 \\
\hline 42 & 2,13 & 7,7 & 531,8 & 75,66 & 116,3 & 0,452 & 202 & $<0$ & $<0$ & 1,1 & $<0$ & 65,4 \\
\hline 43 & 2,42 & 7,79 & 585,6 & 29,71 & 57,38 & 0,009 & 190 & $<0$ & $<0$ & 5,5 & $<0$ & 79,5 \\
\hline 44 & 2,2 & 7,75 & 512,1 & 26,02 & 116,9 & 0,004 & 183,4 & $<0$ & $<0$ & 1,08 & $<0$ & 67,4 \\
\hline 45 & $<0$ & 1,62 & 481,8 & 3,64 & 85,06 & 0,103 & 6,82 & 129 & $<0$ & 4,5 & 0,4 & 0,4 \\
\hline 46 & $<0$ & 5,63 & 5,09 & 5,72 & 20,16 & 0,119 & 1,74 & $<0$ & $<0$ & 0,385 & 4,9 & 4,93 \\
\hline 47 & $<0$ & 1,43 & 39,03 & 13,26 & 22,91 & 0,113 & 1,93 & 4,23 & $<0$ & 2,61 & 4,3 & 4,33 \\
\hline 48 & $<0$ & 2,34 & 99,38 & 118,3 & 28,11 & 0,109 & 1,73 & 12,8 & $<0$ & 2,93 & 3,8 & 3,84 \\
\hline 49 & $<0$ & 4,5 & 566,9 & 24,44 & 39,9 & 0,131 & 10,23 & 101 & $<0$ & 1,53 & 2,3 & 2,3 \\
\hline 50 & $<0$ & 1,2 & 79,56 & 4,89 & 24,24 & 0,092 & 2,2 & 9,98 & $<0$ & 1,02 & 4,4 & 4,44 \\
\hline 51 & $<0$ & 3,3 & 252,3 & 14,78 & 31,03 & 0,082 & 2,96 & 28,1 & $<0$ & 1,68 & 2,8 & 2,84 \\
\hline 52 & $<0$ & 4,3 & 236,3 & 16,96 & 35,43 & 0,084 & 2,49 & 35,9 & $<0$ & 3,06 & 1,1 & 1,16 \\
\hline Ort. & 1,5 & 3,8 & 424,2 & 35,14 & 60,11 & 0,157 & 94,51 & 59,48 & 51,21 & 3 & 0,46 & 26,6 \\
\hline
\end{tabular}

\subsubsection{Demir (Fe)}

52 örnek içerisinde demir değeri en yüksek \% 3,3 ve ortalaması \%1,5'dir. Çevre şehircilik Bakanlığının Topraklardaki kirliliğe ait yönetmelikte $\mathrm{Fe}$ ile ilgili bir standart değer bulunmamaktadır. Ancak topraklardaki genel $\mathrm{Fe}$ oranının \%1-10 arasında değiştiği [16] bilinmekte olup WHO ve FAO verilerine göre de ortalama $\% 5$ 'dir [13]. Sonuçlar bu standartlarla karşılaştırıldığında, $\mathrm{Fe}$ ortalamasının \%1,5 civarında olması, demir kaynaklı bir kirlilik olmadığını göstermektedir (Şekil 4).

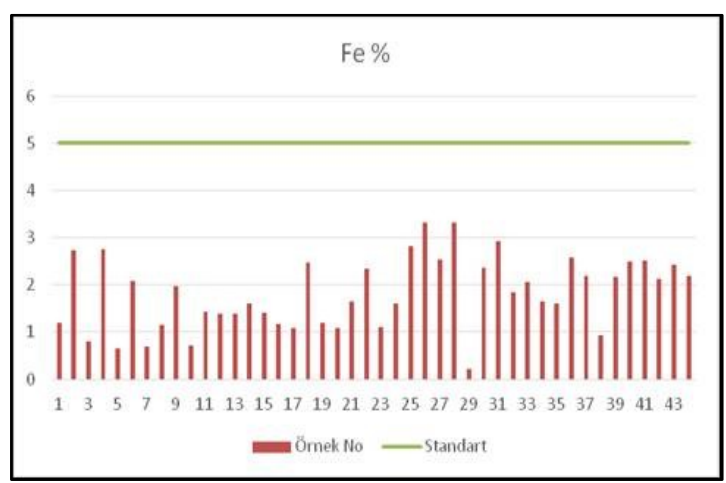

Şekil 4. Örneklerdeki Fe element miktarı (\%)

\subsubsection{Alüminyum (Al)}

Alınan örnekler içerisinde en yüksek Al değeri $\% 9,7$ en düşük değeri \%0,9 ve ortalama değeri de
$\% 3,8$ olarak tespit edilen $\mathrm{Al}$ için literatürde topraklar ile ilgili herhangi bir standart değere rastlanmamıștır. Ancak dünya genelindeki toprakların $\mathrm{Al}$ içeriğinin $\% 1$ ile $\% 5$ arasında değiştiği kabul edildiğinden, çalışma alanı ve civarındaki bazı bölgelerde Al kaynaklı bir kirlilikten söz edilebilir (Şekil 5).

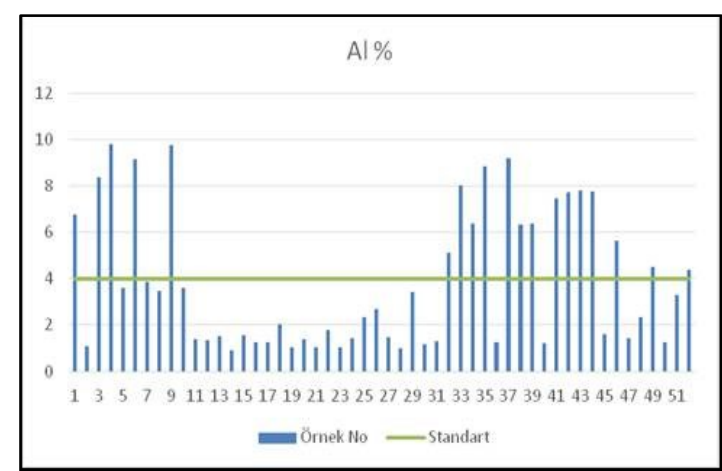

Şekil 5. Örneklerdeki Al element miktarı (\%)

\subsubsection{Mangan (Mn)}

Mangan (Mn) elementinin analiz sonuç değerleri, $\mathrm{mg} / \mathrm{kg}$ cinsinden saptanmıştır. Alınan örnekler içerisinde en yüksek değeri $1135 \mathrm{mg} / \mathrm{kg}$, en düşük değeri 5,09 mg/kg ortanca değeri de 424,2 mg/kg olarak tespit edilmiştir. $\mathrm{Bu}$ sonuçlar toprakta $\mathrm{Mn}$ değeri WHO, FAO'nun belirttiği değer olan $2000 \mathrm{mg} / \mathrm{kg}$ 'ın altındadır [13]. Bu nedenle $\mathrm{Mn}$ değerleri sınırlar içerisinde bulunmaktadır (Şekil 6). 


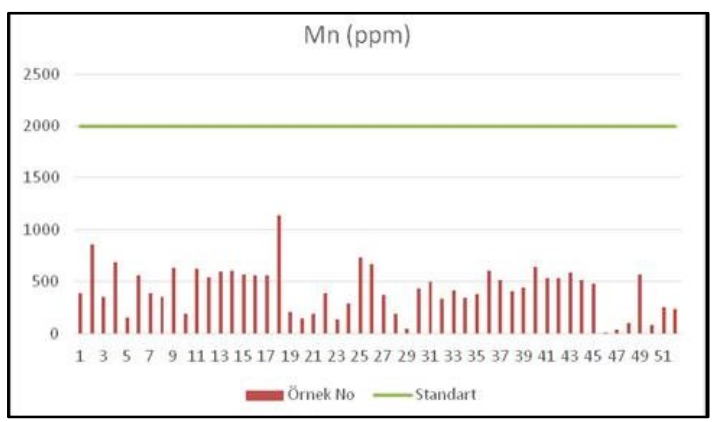

Şekil 6. Mn element miktarını gösteren diyagram

\subsubsection{Bakır (Cu)}

Alınan örnekler de bakır değeri en yüksek $544,5 \mathrm{mg} / \mathrm{kg}$ ortalama değer ise $35,14 \mathrm{mg} / \mathrm{kg}$ 'dır. Bazı örnekler AAS cihazının dedeksiyon limitlerinin altında kalması nedeni ile sonuçlarda $<0$ olarak belirtilmiştir. Çevre ve Şehircilik Bakanlığının $\mathrm{Cu}$ için belirttiği Türkiye kirlilik sınırı 140 mg/kg'dır [14]. 2 örnek Türkiye standartlarının üzerinde çıkmıştır. Bu örneklerden 30 numaralı örnek Seyhan Nehri'ndeki çökellerden, 11 nolu örnek ise E5 karayolu yakınından alınmıştır (Şekil 7).

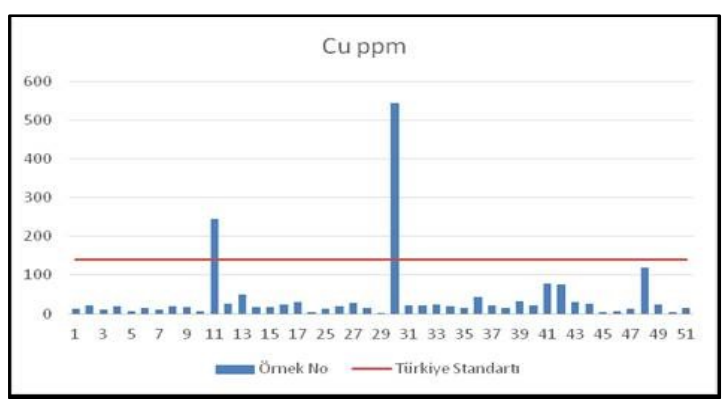

Şekil 7. $\mathrm{Cu}$ element miktarını gösteren diyagram. Sonuçlar $\mathrm{mg} / \mathrm{kg}$ olarak verilmiştir

\subsection{5. Çinko (Zn)}

Çinko (Zn) elementinin analiz sonuçları $\mathrm{mg} / \mathrm{kg}$ cinsinden tespit edilmiştir: Alınan örnek içerisinde en yüksek değeri $366,3 \mathrm{mg} / \mathrm{kg}$, en düşük değeri $8,52 \mathrm{mg} / \mathrm{kg}$ ve ortalama değeri de $60,11 \mathrm{mg} / \mathrm{kg}$ olarak saptanmıştır. 11 numaralı örnek Çevre Yönetmenliği'ne göre belirlenen Türkiye kirlilik standardı olan $300 \mathrm{mg} / \mathrm{kg}$ 'ın üzerinde çıkmıştır [14]. 11 numaralı örnek E5 karayolu yakınından alınmıştır. Diğer örnekler kirlilik sınırının altında kalmıştır (Şekil 8).

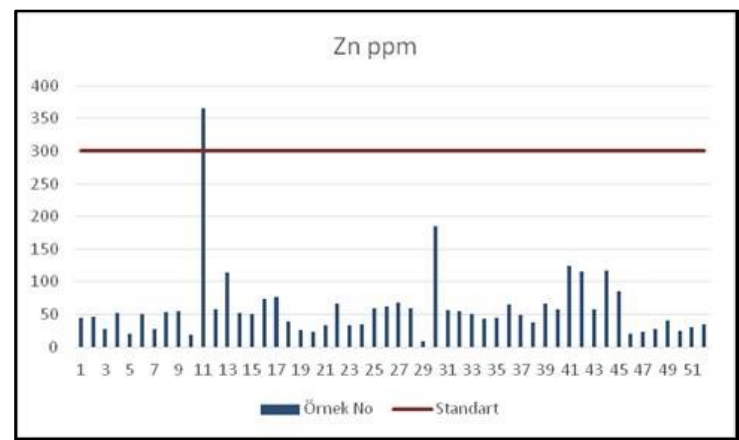

Şekil 8. Zn element miktarını gösteren diyagram

\subsubsection{Civa (Hg)}

C1va değeri en yüksek $3,67 \mathrm{mg} / \mathrm{kg}$ ortalaması ise $0,157 \mathrm{mg} / \mathrm{kg}$ 'dir. En düşük değer 0 olarak saptanmıştır. 5 nolu örnek dışındaki tüm örnek Türkiye standartları olan 1,5 mg/kg'ın altında bulunmaktadır (Şekil 9).

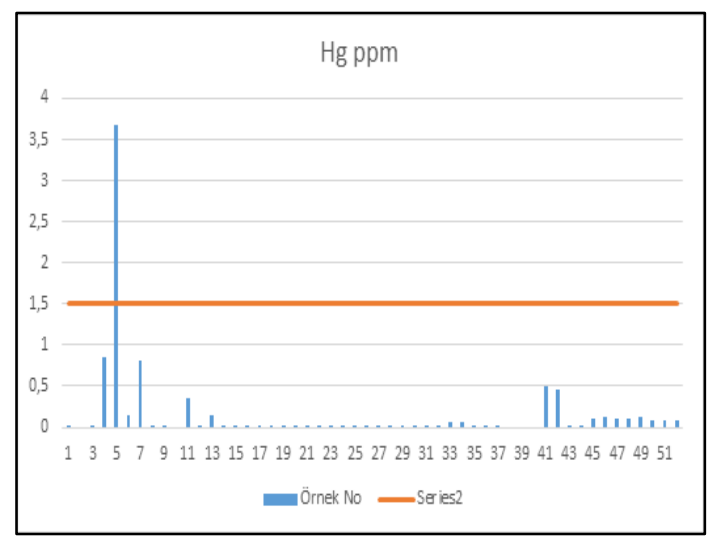

Şekil 9. Hg element miktarını gösteren diyagram. Sonuçlar $\mathrm{mg} / \mathrm{kg}$ olarak verilmiştir

\subsubsection{Nikel (Ni)}

Toprak örneklerinden yapılan analizler sonucunda $\mathrm{Ni}$ değeri en yüksek $366,9 \mathrm{mg} / \mathrm{kg}$ ortalaması ise 94,51 mg/kg'dır. Türkiye kirlilik standartı $75 \mathrm{mg} / \mathrm{kg}$ 'dır. Seyhan nehrine ait sediman örneklerinde $\mathrm{Ni}$ değeri dedeksiyon limitlerinin altında çıkması nedeni ile $<0$ kabul edilmiştir. Alınan örneklerin büyük kısmı Türkiye kirlilik 
Sınırı olan $75 \mathrm{mg} / \mathrm{kg}$ ’ı üzerinde bulunmaktadır (Şekil 10).

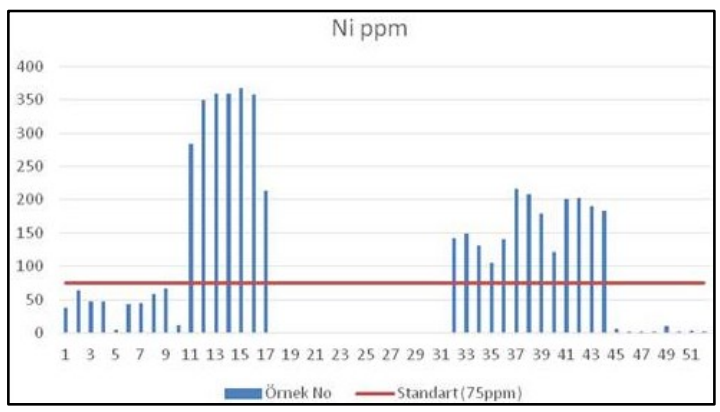

Şekil 10. Ni element miktarını gösteren diyagram. Sonuçlar $\mathrm{mg} / \mathrm{kg}$ olarak verilmiştir

\subsection{8. $\operatorname{Krom}(\mathrm{Cr})$}

Krom elementinin analiz sonuçlarına $\mathrm{mg} / \mathrm{kg}$ cinsinden şu şekilde tespit edilmiştir: Alınan 52 örnek içerisinde en yüksek değeri $267,2 \mathrm{mg} / \mathrm{kg}$ ve ortalama değeri de $59,48 \mathrm{mg} / \mathrm{kg}$ olarak saptanmıştır. Bazı örnekler dedeksiyon limitlerinin altında kalması nedeni ile sonuçlarda $<0$ olarak belirtilmiştir. Örneklerden Özellikle Seyhan nehrine ait sediman örneklerinde $\mathrm{Cr}$ değerleri Türkiye Standartlarının üzerinde çıkmıştır. $\mathrm{Bu}$ çevresel kirliliğin yanında nehri besleyen noktaların yakınlarında bulunan krom cevherleșmesinden kaynaklandığı düşünülmektedir (Şekil 11).

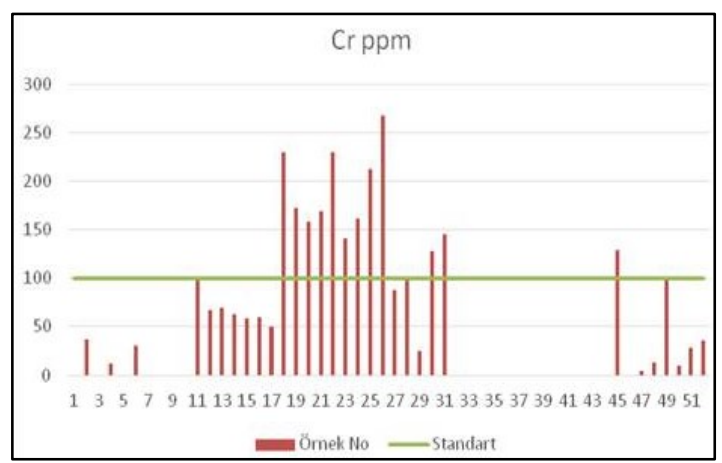

Şekil 11. Cu element miktarını gösteren diyagram

\subsubsection{Kurşun $(\mathrm{Pb})$}

Araziden alınan 52 adet önek üzerinde sadece 20 örnek üzerinde sonuç alınmış diğer örnekler dedeksiyon limitin altında kalmıştır. En yüksek değer $454,1 \mathrm{mg} / \mathrm{kg}$, ortalama değeri ise $51,21 \mathrm{mg} / \mathrm{kg}$ gelmektedir. Türkiye standard 1 $300 \mathrm{mg} / \mathrm{kg}$ olup, tek bir örnek dişında örnekler sınırın altında kalmaktadır (Şekil 12).

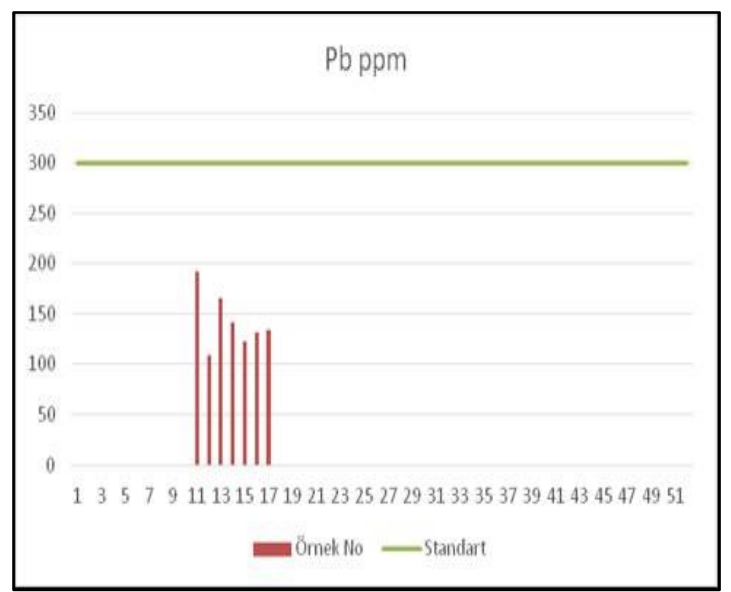

Şekil 12. Pb element miktarını gösteren diyagram

\subsubsection{Arsenik (As)}

Arsenik elementine ait analiz sonuçlara göre en yüksek değer $16,02 \mathrm{mg} / \mathrm{kg}$, ortalama $3 \mathrm{mg} / \mathrm{kg}$ minumum değer ise $0,0004 \mathrm{mg} / \mathrm{kg}$ saptanmıştır. Çevre ve Şehircilik Bakanlığı Toprak Kirlilik yönetmenliğinde Arsenik elementine ait standart bulunmamakta olup, WHO ve FAO değerlerini baz alarak $20 \mathrm{mg} / \mathrm{kg}$ olarak belirtilmiştir [13]. Arsenik değeri örneklerin tamamında standartın altında kalmıştır (Şekil 13).

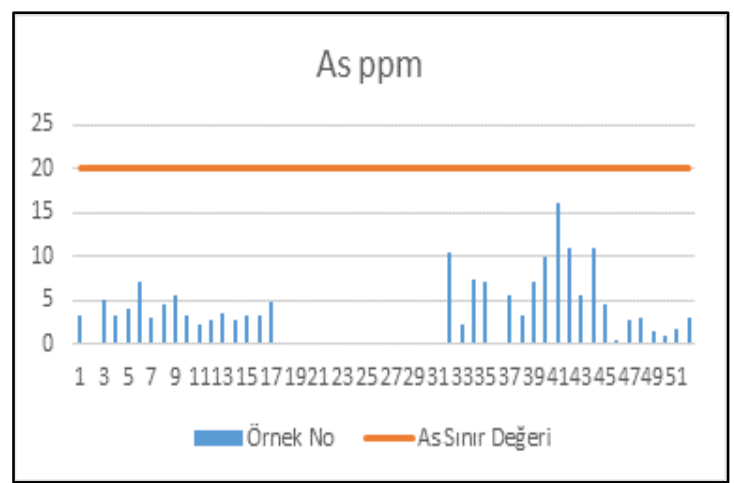

Şekil 13. As element miktarını gösteren diyagram 


\subsubsection{Kadmiyum (Cd)}

Kadmiyum elementi için 8 lokasyondan değer alınmıştır. Diğer noktalarda dedeksiyon limitlerinin altında kalması sebebi ile sonuçlar $<0$ olarak belirtilmiştir. $\mathrm{Cd}$ için en yüksek değer $4,9 \mathrm{mg} / \mathrm{kg}$, ortalama değer ise $0,46 \mathrm{mg} / \mathrm{kg}$ olarak bulunmuştur. $46,47,48$ ve 50 nolu örnekler Türkiye kirlilik sınırlarının üzerinde bulunmuştur (Şekil 14).

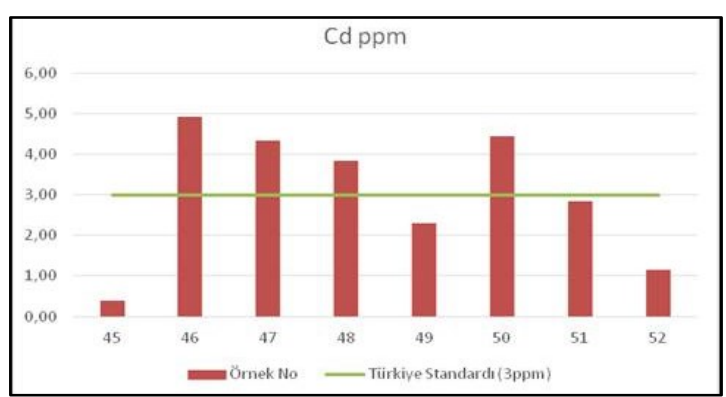

Şekil 14. Cd element miktarını gösteren diyagram. Sonuçlar $\mathrm{mg} / \mathrm{kg}$ olarak verilmiştir

\subsubsection{Kobalt (Co)}

Kobalt elementine ait analiz sonuçlarında en yüksek değer $79,5 \mathrm{mg} / \mathrm{kg}$, ortalama değer $26,6 \mathrm{mg} / \mathrm{kg}$ dır. Bazı örneklerde AAS okumaları dedeksiyon limitlerinin altında olması nedeni ile $<0$ olarak alınıştır. Şekil 15 'de görüleceği üzere Seyhan nehrine ait sedimanların dışındaki bölgelerde Co kirlilik standartı olarak belirlenen $50 \mathrm{mg} / \mathrm{kg}$ 'lık değerin üzerinde çıkmaktadır (Şekil 15).

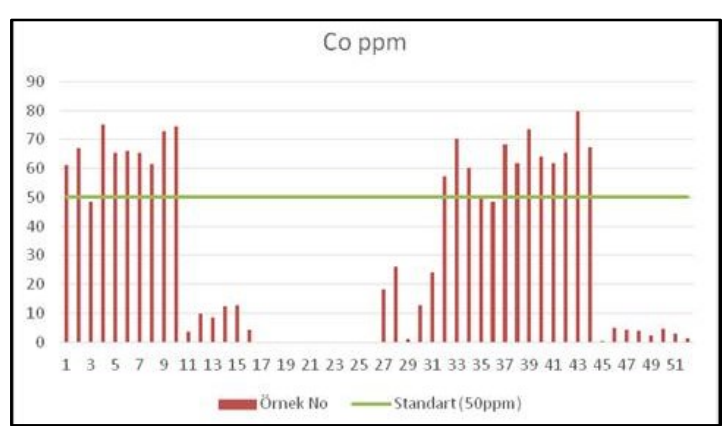

Şekil 15. Co element miktarını gösteren diyagram. Sonuçlar $\mathrm{mg} / \mathrm{kg}$ olarak verilmiştir

\subsection{Ef (Zenginleşme faktörü)}

Zenginleşme faktörü farklı çevresel ortamların değerlendirilmesinde ve metal kirliliğinde antropojenik katkının hesaplanmasında da çok sık kullanılan bir değerdir. İlk kez Buat-Menard ve Chesselet [17] tarafindan ortaya atılan bu faktörün hesaplanmasında, bir referans element seçilerek normalleştirme yapılmaktadır. Normalleştirmede kullanılacak elementin seçimi konusunda kesin bir kabul olmamakla birlikte, genellikle alüminyum, demir, lityum, zirkon ve titanyum gibi jeokimyasal olarak aktif olmayan elementler kullanılır [18-26] $\mathrm{Bu}$ çalışmada ise normalleştirme işlemi Al'a göre hesaplanmıştır.

Ef: ((C Metal Örnek) / CRef (Örnek))/(CMetal (Kabuk) / CRef (Kabuk))). Çıkan sonuçların değerlendirilmesi ise şu şekildedir: $<1$ zenginleşme yok, 1-3 az zenginleşme, 3-5 orta zenginleşme, 5-10 ortaca aşırı zenginleşme, 10-25 aşırı zenginleşme, 25-50 çok aşırı zenginleşme, >50 max. Zenginleşme [27]. Formüldeki EF: Zenginleşme faktörü, C Metal (Örnek): İlgili elementin konsantrasyonunu, CRef (Örnek): referans olarak alınan elementin ölçülen konsantrasyonunu, CMetal (Kabuk): İlgili elementin kabuktaki ardalan (background) değerini, CRef (Kabuk): referans olarak alınan elementin kabuktaki ardalan (background) değerini tanımlamaktadır [28]. Bu formüle göre hesaplanan Ef sonuçları değerlendirildiğinde; 1-10 arasındaki toprak örneklerinde sadece Mn değeri 1-3 arasında olup az zenginleşme göstermektedir. 11-17 toprak örneklerinde $\mathrm{Fe}, \mathrm{Cr}$, Mn değerleri 1-3 arasında az zenginleşme;

$\mathrm{Cu}, \mathrm{Zn}$ değerleri 3-5 arasında orta zenginleşme; $\mathrm{Ni}$, Co değerleri ise 5-10 arası olup ortaca aşırı zenginleşme göstermektedir. 18-31 arası sediman örneklerinde Fe, Mn 1-3 arası az zenginleşme; zenginleşme; $\mathrm{Co}, \mathrm{Cu} 3-5$ arasında ortaca zenginleşme; $\mathrm{Zn}, \mathrm{Cr}$ değerleri ise 5-10 arası olup ortaca aşırı zenginleşme göstermektedir. 32-44 arası toprak örneklerinde $\mathrm{Zn}, \mathrm{Ni}$, Co değerleri 1-3 arasında az zenginleşme göstermektedir. 45- 52 arasında toprak örneklerinde ise $\mathrm{Mn}, \mathrm{Ni}, \mathrm{Cr}, \mathrm{Co}$, 
Fe 1-3 arasında az zenginleşme; Zn 5-10 arasında ortaca aşırı zenginleşme; $\mathrm{Cd}$ değerleri 10-25 arasında aşırı zenginleşme göstermektedir (Çizelge 3).

Çizelge 3. Zenginleşme Faktörü sonuçları

\begin{tabular}{|l|c|c|c|c|c|}
\hline & $1-10$ (toprak) & $\begin{array}{c}11-17 \\
\text { (toprak) }\end{array}$ & $\begin{array}{c}18-31 \\
\text { (sediman) }\end{array}$ & 32-44 (toprak) & $45-52$ (toprak) \\
\hline$<1$ (zenginleşme yok) & $\begin{array}{c}\mathrm{Cu}, \mathrm{Zn}, \mathrm{Cr}, \mathrm{Fe}, \\
\mathrm{Hg}, \mathrm{As}, \mathrm{Mn}\end{array}$ & $\mathrm{Hg}, \mathrm{As}$ & $\mathrm{Hg}, \mathrm{As}$ & $\begin{array}{c}\mathrm{Hg}, \mathrm{As}, \mathrm{Fe}, \mathrm{Mn}, \\
\mathrm{Cu}, \mathrm{Cr}, \mathrm{Cd}\end{array}$ & $\mathrm{Hg}, \mathrm{As}$ \\
\hline 1-3 (az zenginleşme) & $\mathrm{Mn}$ & $\mathrm{Fe}, \mathrm{Cr}, \mathrm{Mn}$ & $\mathrm{Fe}, \mathrm{Mn}$ & $\mathrm{Zn}, \mathrm{Ni}, \mathrm{Co}$ & $\begin{array}{c}\mathrm{Mn}, \mathrm{Ni}, \mathrm{Cr}, \mathrm{Co}, \\
\mathrm{Fe}\end{array}$ \\
\hline 3-5 (orta zenginleşme) & - & $\mathrm{Cu}, \mathrm{Zn}$ & $\mathrm{Co}, \mathrm{Cu}$ & - & - \\
\hline $5-10$ (ortaca aşırı zenginleşme) & - & $\mathrm{Ni}, \mathrm{Co}$ & $\mathrm{Zn}, \mathrm{Cr}$ & - & $\mathrm{Zn}$ \\
\hline 10-25 (aşırı zenginleşme) & - & - & - & - & $\mathrm{Cd}$ \\
\hline 25-50 (ortaca aşırı zenginleşme) & - & - & - & - & - \\
\hline
\end{tabular}

\subsection{Kirlilik Faktörü (Cf ) ve Kirlilik Derecesi (Cd)}

Ağır metallerin çevreye olan etkileri sinerjik ve antogenistik olmak üzere iki tiptir. Kirlilik seviyesi "Kirlilik Faktörü (Cf)" olarak ifade edilmektedir [29]. Kirlilik faktörünün hesaplanması için "Ortalama eşik değerleri”" [30] veya "Ortalama yer kabuk değerleri” kullanılır [31]. Kirlilik faktörü $(\mathrm{Cf})=$ Sedimentteki metal konsantrasyonu/Metalin ortalama eşik değeri olarak hesap edilir. Kirlilik faktörü 4 grupta sınıflandırılır [32] $\mathrm{Cf}<1$ : düşük; $1 \leq \mathrm{Cf}<3$ : orta; $3 \leq \mathrm{Cf}<6$ : önemli ve $\mathrm{Cf} \geq 6$ : çok yüksek kirlilik faktörü. Kirlilik faktörü örnekler üzerinde hesaplandığında; 1-10 $(8,635)$ ve 32-44 nolu örnekler (10-135) arasında Al çok yüksek kirli, 32-44 nolu örneklerde Co 3,459 mg/kg ile önemli derecede kirli sınıfinda yer almaktadır. Ni, As, $\mathrm{Hg}, \mathrm{Zn}, \mathrm{Cu}$, Fe elementleri ise düşük derecede kirli sınıfındadır (Çizelge 4). "Kirlilik Derecesi (Cd)" belirli bir basenin tüm kirlilik faktörlerinin toplamıdır. Bu çalışmada, Sedimentdeki $\mathrm{Hg}, \mathrm{Cd}$, $\mathrm{Pb}, \mathrm{Cr}, \mathrm{Cu}, \mathrm{Mn}, \mathrm{Ni}, \mathrm{Zn}, \mathrm{Fe}$ ve Al için $\mathrm{Cf}$ hesaplandığında, kirlilik derecesi aşağıda ki gibi 4 grupta değerlendirilir: $\mathrm{C}_{\mathrm{d}}<10$ : düşük; $10 \leq \mathrm{C}_{\mathrm{d}}<$ 20: orta; $20 \leq \mathrm{C}_{\mathrm{d}}<40$ : önemli ve $\mathrm{C}_{\mathrm{d}} \geq 40$ : çok yüksek dereceli kirlilik [32]. Buna göre $(\mathrm{Cd})$ göre 11-17 ve 18-31 arası örnekler düşük, 1-10 $(15,088)$ ile $45-52$ arasındaki örnekler $(15,195)$ orta dereceli kirlidir.

Ayrıca, çalışma kapsamında tespit edilen kirliliğin derecesini yorumlayabilmek için Jeo-birikim indeks değerleri (Igeo) hesaplanmıştır (Çizelge 5). $0<$ lgeo Kirlenmemiş, $0-1 \quad$ Kirlenmemiş-orta derecede kirli, 1-2 orta derecede kirli, 2-3 orta kuvvette kirli, 2-4 Aşırı kirli, 4-5 aşırı-çok aşırı kirli, lgeo $>5$ çok aşırı kirli [33-35]. 1-10 arasında ki örneklerde Co değeri Jeo birikim indeksine göre $1-10$, 32-44 arasındaki örneklerde Co $(1,19)$ Kirlenmemiş-Orta derecede kirli. 11-31, 45-52 arasındaki örneklerde Kirlenmemiş sıfında yer almaktadır. Ni değerleri jeo birikim değerlerine göre Ortalama 0-0,478 arasinda olup, Kirlenmemiş-Orta derecede kirlidir.

lgeo $\mathrm{As}, \mathrm{Cr}, \mathrm{Cu}$, fe ve $\mathrm{Al}$ değerleri kirlenmemiş sinıfinda yer almaktadir.

Çizelge 4. Kirlilik faktörü ve kirlilik derecesi değerleri

\begin{tabular}{|c|c|c|c|c|c|c|c|c|c|c|c|c|}
\hline & & Co & $\mathrm{Ni}$ & As & $\mathrm{Hg}$ & $\mathrm{Cr}$ & $\mathrm{Zn}$ & $\mathrm{Mn}$ & $\mathrm{Cu}$ & $\mathrm{Fe}$ & $\mathrm{Al}$ & $\mathrm{Cd}$ \\
\hline \multirow{2}{*}{$1-10$} & Cf & 3,45 & 0,62 & 0,3 & 0,39 & $\begin{array}{l}0,08 \\
\end{array}$ & 0,42 & 0,53 & 0,31 & 0,31 & 8,63 & \\
\hline & $\mathrm{Cd}$ & 15,08 & & & & & & & & & & \\
\hline \multirow{2}{*}{$11-17$} & $\mathrm{Cf}$ & 0,38 & 4,8 & 0,24 & 0,06 & 0,74 & 1,19 & 0,68 & 0,29 & 0,28 & 0,16 & \\
\hline & $\mathrm{Cd}$ & 9,86 & & & & & & & & & & \\
\hline \multirow{2}{*}{$18-31$} & $\mathrm{Cf}$ & 0,3 & 0,001 & 0,001 & 1,76 & 3,1 & 0,45 & 1,03 & 0,43 & 0,2 & 0,01 & \\
\hline & $\mathrm{Cd}$ & 7,32 & & & & & & & & & & \\
\hline \multirow{2}{*}{$32-44$} & $\mathrm{Cf}$ & 3,35 & 2,45 & 0,57 & 0,06 & 0,001 & 0,71 & 0,56 & 0,72 & 0,43 & 10,1 & \\
\hline & $\mathrm{Cd}$ & 19,02 & & & & & & & & & & \\
\hline \multirow{2}{*}{$45-52$} & $\mathrm{Cf}$ & 0,15 & 0,05 & 0,17 & 0,07 & 0,44 & 0,37 & 0,25 & 0,56 & 0,001 & 2,99 & 10,0 \\
\hline & $\mathrm{Cd}$ & 15,19 & & & & & & & & & & \\
\hline
\end{tabular}


Çizelge 5.Toprak ve sediman numunelerinin Jeo-Birikim İndeks Değerleri (Igeo)

\begin{tabular}{|c|c|c|c|c|c|c|c|c|c|c|}
\hline & $\begin{array}{l}\text { lgeo } \\
(\mathrm{Co})\end{array}$ & $\begin{array}{c}\text { lgeo } \\
(\mathrm{Ni})\end{array}$ & lgeo $(\mathrm{As})$ & $\begin{array}{c}\text { lgeo } \\
(\mathrm{Hg})\end{array}$ & lgeo $(\mathrm{Zn})$ & lgeo $(\mathrm{Cr})$ & $\begin{array}{c}\text { lgeo } \\
(\mathrm{Mn})\end{array}$ & $\begin{array}{c}\text { lgeo }(\mathrm{Cu}) \\
\begin{array}{c}\text { lgeo } \\
(\mathrm{Fe})\end{array}\end{array}$ & $\begin{array}{c}\text { lgeo } \\
(\mathrm{Al})\end{array}$ \\
\hline $1-10$ & 1,20 & 0,48 & $-2,73$ & 0,26 & $-0,76$ & $-1,94$ & $-1,66$ & $-2,41$ & $-2,47$ & 2,38 \\
\hline $1-17$ & $-1,64$ & 0,00 & $-4,05$ & 0,04 & $-1,05$ & $-0,72$ & $-1,14$ & $-0,94$ & $-2,39$ & $-3,21$ \\
\hline $18-31$ & $-0,49$ & 0,00 & $-12,06$ & 0,00 & 0,07 & $-1,22$ & $-2,13$ & $-1,36$ & $-2,02$ & $-2,96$ \\
\hline $32-44$ & 1,15 & 0,35 & $-1,95$ & 0,04 & 0,00 & $-1,18$ & $-1,44$ & $-1,25$ & $-1,82$ & 2,71 \\
\hline $45-52$ & $-3,57$ & 0,00 & $-3,18$ & 0,05 & $-2,10$ & $-2,14$ & $-3,50$ & $-2,34$ & 0,00 & 0,72 \\
\hline
\end{tabular}

\section{SONUÇ}

Araştırma kapsamında 52 adet örnek alınmıştır. Bu örnekler Adana şehir merkezi ve çevresinden toprak örnekleri ile şehir merkezinden geçen Seyhan nehrine ait sediman örneklerinden oluşmaktadır. Örnekler üzerinde, Atomik Absorbsiyon Spektrometre cihazı ile $\mathrm{Fe}, \mathrm{Al}, \mathrm{Mn}$, $\mathrm{Pb}, \mathrm{Zn}, \mathrm{Cr}, \mathrm{Co}, \mathrm{Ni}, \mathrm{Cr}, \mathrm{Cu}, \mathrm{Hg}, \mathrm{As}, \mathrm{Cd}$ element analizleri yapılmıştır. Analiz sonuçları Çevre ve Şehircilik Bakanlığı Kirlilik yönetmenliğine ait standartlar ve bu standartlarda bulunmayan elementler için ise Uluslararası (WHO-FAO) standartlarla karşılaştırılarak kirlilik oluşturup oluşturmadığı ve element birikimleri hakkında bilgi edinilmiştir. Bu sonuçlara göre: Adana şehir merkezi ve çevresinde $\mathrm{Fe}$ ortalaması \%1,5'tir. Fe için standardın $\% 5$ olması sebebiyle, demir kaynaklı bir kirlilik bulunmamaktadır.

Topraklarda Al içeriğinin $\% 1$ ile $\% 5$ arasında değiştiği kabul edilmektedir. Alınan örneklerin büyük kısmı yüksek çıkmaktadır. Ancak Seyhan nehrinden alınan örnekler standardın oldukça altında görülmektedir. Kirlilik faktörü (Cf) göre çok kirli. Kirlilik derecesine (Cd) görede orta derece kirli, jeo birikim indeksine görede orta kuvvetli kirli sınıfında çıkmaktadır. Bu nedenle şehir merkezi ve sanayi bölgelerinde Al kaynaklı bir kirlilikten söz edilebilir. İnceleme alanında Fe, $\mathrm{Mn}$, As ve $\mathrm{Zn}$ element içerikleri standartların altında bulunmaktadır.

Toprak örneklerinden yapılan analizler sonucunda $\mathrm{Ni}$ değeri en yüksek $366,9 \mathrm{mg} / \mathrm{kg}$ ortalaması ise 94,51 mg/kg'dır. Türkiye kirlilik standartı $75 \mathrm{mg} / \mathrm{kg}$ 'dir. Alınan örneklerin büyük kısmı Türkiye kirlilik sınırı olan $75 \mathrm{mg} / \mathrm{kg}$ 'ın üzerinde bulunmaktadır. Kirlilik faktörü (Cf) 11-10,18-31 ve 45-52 nolu örnekler arasında göre düşük kirli. 11-17 arasında önemli kirli, 32-44 arasındaki örneklerde orta kirli sinıfındadır. Kirlilik derecesine (Cd) görede orta derece kirli, jeo birikim indeksine görede kirlenmemiş-az kirli orta çıkmaktadır. $\mathrm{Bu}$ kirliliğin çevresel etkenlerin sonucu ile birlikte kismen de bölgenin üst kesimlerde bulunan ofiyolitik istiflerden de kaynaklanabileceği düşünülmektedir.

C1va değeri en yüksek $3,67 \mathrm{mg} / \mathrm{kg}$ ortalaması ise $0,157 \mathrm{mg} / \mathrm{kg}$ 'dir. 5 nolu örnek dişındaki tüm örnek Türkiye standartları olan $1,5 \mathrm{mg} / \mathrm{kg}$ '1n altında bulunmaktadır. Kirlilik faktörü (Cf) göre düşük. Kirlilik derecesine, jeo birikim indeksine göre de kirlenmemiş sınıfında çıkmaktadır.

Güldiren ve Tekin [11], farklı mevsimlerde Seyhan baraj gölündeki sedimanlar üzerinde yaptıkları çalışmaları ile bu çalışmadaki sonuçlar karşılaştırmıştır. Buna göre; Fe içeriği Güldiren ve Tekin [11]'a göre 1635,07 $\mathrm{mg} / \mathrm{kg}$ ile $32568,98 \mathrm{mg} / \mathrm{kg}$ arasında değişiklik göstermekte iken bu araştırmada ise en yüksek $33000 \mathrm{mg} / \mathrm{kg}$ 'dır. Adana şehir merkezi ve çevresinde $\mathrm{Fe}$ ortalaması \%15000 mg/kg'dır. Fe için standardın $50000 \mathrm{mg} / \mathrm{kg}$ olması sebebiyle, demir kaynaklı bir kirlilik bulunmamaktadır.

Seyhan Göl sedimanlarında $\mathrm{Pb}$ değeri 1,70-24,87 mg/kg arasında değişiklik gösterdiği belirtilirken seyhan nehri sedimentlerinde en yüksek değer 454,1 mg/kg dır. Kurşun için Türkiye standard1 $300 \mathrm{mg} / \mathrm{kg}$ olup, bir örnek dışında örnekler bu sınırın altında kalmaktadır.

Mn değeri ise Güldiren ve Tekin [11] çalışmasında 23,88-926,73 $\mathrm{mg} / \mathrm{kg}$ arasında değişiklik gösterirken bu araştırmada 5,09-1135 $\mathrm{mg} / \mathrm{kg}$ arasında değişmektedir. Mn değerleri standartta belirtilen $2000 \quad \mathrm{mg} / \mathrm{kg}$ 'lı kirlilik sınırının altındadır. 
Güldiren ve Tekin [11] çalışmasında $\mathrm{Cu}$ düzeyi 3,96-34,78 $\mathrm{mg} / \mathrm{kg}$ arasında değişirken bu araştırmada Seyhan Nehri sedimentlerinde de ortalama $0-544,5 \mathrm{mg} / \mathrm{kg}$ arasında değişmektedir. Bakır Türkiye kirlilik sınırı 140 mg/kg'dır. 2 örnek Türkiye Standartları'nın üzerinde çıkmıştır. Bu örneklerden 30 numaralı örnek Seyhan nehrindeki çökellerden 11 nolu örnek ise E5 karayolu yakınından alınmıştır.

Zn değerlerine bakıldığında Güldiren ve Tekin [11] $\mathrm{Zn}$ düzeyinin 50,65-338,80 $\mathrm{mg} / \mathrm{kg}$ arasında değişiklik gösterdiği belirtilirken bu araştırmada Seyhan Nehri sedimentlerinde 8,52-366,3 mg/kg arasında değiştiği görülmektedir. 11 numaralı örnek Çevre yönetmenliğine göre belirlenen Türkiye kirlilik standardı olan 300 mg/kg'ın üzerinde çıkmıştır.

Cr değerleri Güldiren ve Tekin [11] çalışmasına göre $5,20-114,81 \mathrm{mg} / \mathrm{kg}$ arasında değişiklik gösterdiği belirtirken bu araştırmada en yüksek $267,2 \mathrm{mg} / \mathrm{kg}$, ortalama ise $59,48 \mathrm{mg} / \mathrm{kg}$ 'dır. Türkiye standartı olan $100 \mathrm{mg} / \mathrm{kg}$ üzerinde 13 örnek saptanmıştır. $\mathrm{Bu}$ örneklerde Seyhan nehrine ait sedimanlardan gelmektedir. $\mathrm{Bu}$ sedimanların Kirlilik faktörü (Cf) 3,1 orta- yüksek kirli. Kirlilik derecesine $(\mathrm{Cd})$ görede düşük kirli sınıfındadır. Jeo birikim indeksine görede kirlenmemiş-az kirli çıkmaktadır. $\mathrm{Cr}$ elementinin yüksek çıkması çevresel kirliliğin yanında Seyhan nehrini besleyen kaynakların yakınlarında bulunan krom cevherleşmesinden kaynaklandığı düşünülmektedir.

\section{TEŞEKKÜR}

Bu çalışma FBA-2015-4466 proje no'lu Çukurova Üniversitesi Bilimsel Araştırma Projeleri Koordinasyon birimi tarafından desteklenmiştir.

\section{KAYNAKLAR}

1. Türkoğlu, B., 2006. Toprak Kirlenmesi ve Kirlenmiş Toprakların Islahı, Yüksek Lisans Tezi, Ç.Ü. Fen Bilimleri Enstitüsü, Toprak Anabilim Dalı.
2. Tasatar, B., 1995. Topraklarımız ve Toprak Kirliliği, T.C. Çevre Bakanlığı, Çevre Yazıları, 3,72 .

3. Karpuzcu, M., 1996. Çevre Kirlenmesi ve kontrolü. Gebze İleri Teknoloji Enstitüsü. Çevre Mühendisliği Bölümü, İstanbul.

4. Örnektekin, S., 1997. A Study of Heavy Metal Pollution from Motor Vehicle Emissions and its Effect on Soil in İskenderun, North-east Editerranean. Turkish J Eng Env Sci, 21, 45-49.

5. Yükselen, M.A., 2002. Characterization Of Heavy Metal Contaminated Soils in Northern Cyprus, Environmental Geology, 42, 597-603.

6. Vivenstova, E., Kumpiene, J., Gunneriusson, L., Holmgren, A., 2004. Change in Soil Organic Matter Composition and Quantity with Distance to a Nicel Smelter-a Case Study on the Kola Peninsula, Nw Russia, Geoderma, 11.

7. Yaman, S., 1994. Karayolu Kenar Topraklarında Kurşun Kirlenmesi (CeyhanAdana), Jour. of Eng. Env. Sci., No: 19, 303-306.

8. Topak, Y., 1997. Berdan Gölü (Tarsus) Keşbükü-Kulaklı Köyleri Arası Ağır Metal Analizleri ve Mevsimsel Hidrojeokimyasal Değişimleri. Çukurova Üniversitesi Fen Bilimleri Enstitüsü Jeoloji Mühendisliği Anabilim Dalı Yüksek Lisans Tezi, FBE, 95-72.

9. Aysan, H., 1999. Adana-Tarsus Güneyinde Kalan Bölgenin Serbest Akiferlerde ve Topraklardaki Ağır Metal Kirliliğinin Saptanmas1. Çukurova Üniversitesi, Fen Bilimleri Enstitüsü Doktora Tezi.

10. Kurt, M.A., Alpaslan, M., Temel, A., Güler, C., 2014. Deliçay ile Tarsus (Berdan) Çayı Arasındaki Bölgede Yer Alan Kuvaterner Sedimanlarının Mineralojikve Jeokimyasal Özellikleri. Türkiye Jeoloji Bülteni, Cilt 57, Sayı 1.

11. Güldiren, O., Tekin, S., 2017. Seyhan Baraj Gölü (Adana)'nün Suyunda ve Sedimentindeki Bazı Ağır Metallerin Mevsimsel Değişimi. Süleyman Demirel Üniversitesi Yalvaç Akademi Dergisi 2 (1) : 99-111,

12. Internet: https://www.beyince.net

13. Chiroma T. M., Ebewele R. O., Hymore F.K., 2014. Comparative Assessement of Heavy 
Metal Levels in Soil, Vegetables and Urban Grey Waste Water used for Irrigation in Yola and Kano. International Refereed Journal of Engineering and Science, 3(2), 01-09.

14. Çevre ve Şehircilik Bakanlığı, Toprak Kirliliği Kontrolü Yönetmeliği, 2001.

15. Schmidt, G.C., 1961. Stratigraphic Nomenculature for the Adana Region Petroleum District VII. Petroleum Administration Bulletine, 6, 47-63.

16. Kabata-Pendias, A., Pendias, H., 2001. Trace Elements in Soils and Plants, $3^{\text {rd }}$ Ed., Crc Press, Boca Raton, Fl.

17. Buat-Menard, P., Chesselet, R., 1979. Variable Influence of the Atmospheric Flux on the Trace Metal Chemistry of Oceanic Suspended Matter. Earth and Planetary Science Letters, 42 (3), 399-411.

18. Riemann, L., Steward, G. F., Azam, F., 2000. Dynamics of Bacterial Community Composition and Activity During a Mesocosm Diatom Bloom. Applied and Environmental Microbiology, 66(2), 578-587.

19. Schiff, K.C., Weisberg, S.B., 1999. Iron as a Reference Element for Determining Trace Metal Enrichment in Southern California Coastal Shelfsediments. Marine Environmental Research, 48(2), 161-176.

20. Sutherland, B.R., 2000. Internal Wave Reflection in Uniform Shear. Quarterly Journal of the Royal Meteorological Society, 126(570), 3255-3286.

21. Ray, A.K., Tripathy, S.C., Patra, S., Sarma, V.V., 2006. Assessment of Godavari Estuarine Mangrove Ecosystem Through Trace Metal Studies. Environment International, 32(2), 219-223.

22. Huerta-Diaz, M.A., Delgadillo-Hinojosa, F., Hernández-Ayón, M., Segovia-Zavala, J.A., García-Esquivel, Z., López-Zárate, H., Siqueiros-Valencia. A., Galindo-Bect, S., 2008. Diagnosis of Trace Metal Contamination in Sediments: the Example of Ensenada and El Sauzal, Two Harbors in Baja California, Mexico. Marine Environmental Research, 66(3), 345-358.

23. Essien, J.P., Antai, S.P., Olajire, A.A., 2009. Distribution, Seasonal Variations and Ecotoxicological Significance of Heavy Metals in Sediments of Cross River Estuary Mangrove Swamp. Water, Air, and Soil Pollution, 197(1-4), 91-105.

24. Mohiuddin, K.M., Zakir, H.M., Otomo, K., Sharmin, S., Shikazono, N., 2010. Geochemical Distribution of Trace Metal Pollutants in Water and Sediments of Downstream of an Urban River. International Journal of Environmental Science ve Technology, 7(1), 17-28.

25. Zhang, C., Qiao, Q., Piper, J.D., Huang, B., 2011. Assessment of Heavy Metal Pollution from a Fe-smelting Plant in Urban River Sediments using Environmental Magnetic and Geochemical Methods. Environmental Pollution, 159(10), 3057-3070.

26. Galuszka, A., Migaszewski, Z.M., Zalasiewicz, J., 2014. Assessing the Anthropocene with Geochemical Methods. Geological Society, London, Special Publications, 395(1), 221-238.

27. Birth, G., 2003. A Scheme, For Assessing Human Impacts on Coastal Aquatic Environments using Sediments. In: Woodcoffe, C.D., Furness, R.A., (Eds), Coastal Gis.

28. Alak, A., Sümer, Ö., 2017. Marmara ve Karadeniz Kıyılarındaki Güncel Sedimanlar İçinde Antroposen'in Varlığına Ait Yeni Bulgular. Türkiye Jeoloji Bülteni, 60, 145-168.

29. Muthu, S.R., Jayaprakash, M., 2008. Distribution and Enrichment of Trace Metals in Marine Sediments of Bay of Bengal, off Ennore, South-east Coast of India. Environmental Geology, 5(1), 207-217.

30. Turekian, K.K., Wedepohl, K.H., 1961. Distribution of the Elements in Some Major Units of the Earth's Crust. Geological Society of American Bulletin, 72, 175-192.

31. Taylor, S.R., 1972. Abundance of Chemical Elements in the Continental Crust; a New Table. Geochimica et Cosmochimica Acta, 28,1273 .

32. Hakanson, L., 1980. An Ecological Risk İndex for Aquatic Pollution Control-a Sedimentological Approach. Water Research, 14, 975-1001.

33. Müller G., 1961. Index of Geoaccumulation in Sediments of the Rhine River, Geojournal, 2, 108-118. 
34. Chen Y.C., Chen, M.H., 2001. Heavy Metal Concentrations in Nine Species of Fishes Caught in Coastal Waters of Ann-Ping, Journal of Food and Drug Analysis, 9(2), 107- 114.

35. Kırmızıgül, O., 2013. Gökçekaya Baraj Gölü Dip Sedimentinin Ağır Metal Düzeylerinin Belirlenmesi. Gazi Üniversitesi Fen Bilimleri Enstitüsü, Yüksek Lisans Tezi, Ankara. 
